April 12th. - The patient was brought to me to-day. There was very little deformity - in fact, when coming into the room nobudy would notice any whatever. On measuring from the centre of the sternal notch to the tip of the acromion process, there was found to be half an inch difference between the two sides. I put her through different exercises, and perceived that she had perfect movement of her arm on the affected side; she could lift weights, play the piano, dress her hair, and hold her arm at right angles to the trunk-in fact, the movements were equally good with those of the opposite side. Her general health was everything that could be desired. The scar was firm, and there was no trace whatever of any recurrence. (Fig. 2)

Half of the specinen is now in the College of Surgeons nuseum and the other half at the Cancer Hospital. The accompanying drawings of the specimen are about half the real size. (Figs. 3, 4.)

I have thought this case worthy of record, as I believe it not only to be one of the rarest operations in surgery, but also one fraught with the greatest possible anxiety to the surgeon operating, as from the intimate relations of the growth to the large veins situated at the root of the neck, the pleura, and other important vessels and nerves, no one could undertake such an operation without considerable misgivings as to the result. In the case before us I was guided, as I have said, by several considerations to adopt the measure I did, and the result has justified me in the course I adopted. 'The history of the case clearly pointed to the disease commencing in the bone or periosteum; as the growth increased it extended more downwards and forwards along the chest walls than mpwards, and althongh a boss was distinctly felt behind the sternal attachment of the sterno-mastoid muscle, yet I felt sure I could get my finger below it. It is true there was some considerable swelling of the arm, and there had leen some puffiness of the face on the same side as the tumour, pointing to pressure upon the subclavian and internal jugular veins, and the chief anxiety in the operation was centred in the question as to how far these veins were implicated in the growth. I believed they were not in any way involved, but that the growth, being bound down by the clavicle, was presing on the subclavian vein as it passed over the rib. Such proved to be the case, and the subclavius muscle and other tissues intervened between the tumour and the vein, and the bone, with its growth, was easily separated without in any way jeopardising the vessel.

$$
\text { (To be concluded.) }
$$

\section{TUMOUR OF THE PONS VAROLII.}

\section{BY A. MACGREGOR, M.D.,}

aSAISTANT PHYSICIAN TO THE ABERDEEN HOSPITAL FOR SICK CHILDREN.

E. $\mathrm{M}-$, aged eight years, was admitted into the Alberdeen Hospital for Sick Children on Jan. 29th, 1887, and the history then given by her mother was that for two months the child had been getting weaker, frequently suffered from severe headache, and had on several occasions become suddenly sick. She had always been a delicate child, and had twice suffered from bronchitis. She was one of a family of nine, four of whom died at ages ranging from nine months to two years and a half, the causes of death being teething, whooping cough, "disease of the lungs," and tubercular meninuitis; of the five living at the date of the patient's admission one was suffering from phthisis and another had suppurating cervical glands. The father died of "bronchitic asthma." The nother was apparently healthy.

When admitted into the hospital, the patient was a very pale and sickly-looking child, but the most caref ul examination revealed nothing ahnormal in any of the organs or viscera of the body. After admision there was no conplaint of headache, and no sickness until the morning of Feb. 5th, and the next attack was on March 6 th, when the sickness was constant and the stomach immediately rejected everything swallowed. On Mareh 8th ophthalmoscopic examination revealed optic neuritis in the left eye, but the right fundus appeared to be normal. At the same time it was noted that the patellar reflexes were exaggerated, the right more so than the left. Six lays later, the patient was flushed, and lay apparently comatose. There was now exoplithalmos on the left side, and immediately below the centre of the cornea of the left eye there was a superficial abrasion or ulcer, round which the cornea was becoming opaque and softened, and the corneal sensibility was diminished. It was also seen that the leit facial nerve had become involved, that there was paresis of that side of the face; the left patellar reflex was almost lost, and the right greatly dininished. The ophthalmoscope at this date showed that optic neuritis had develeped in the right eye and had increased in the left. On the day following there was considerable extension of the corneal affection in the left eye, and an exactly similar process was seen developing in the right cornea, and there was paresis of the muscles of the right side of the face. The patient swallowed readily and without difficulty. On the previous day there was involuntary micturition; there was now retention, necessitating the use of the catheter. The urine contained neither surar nor albumen. On March 17th the left pupil was half contracted, and the lower half of the cornea was infiltrated with pus; the right pupil was dilated, and the vlceration of the cornea on this side was extending. Both eyeballs were very much injected, and there was a copious discharge of muco-pus. The pulse was a mere thread, and could only occasionally be felt. Two days later the eyeballs were less prominent, and it was then noted that the pulse was 182 per minute. On the morning of March 2lst, it was found that perforation of the left cornea had taken place, and the temperature, which for a week before was $102^{\circ}$ and $103^{\circ}$, was then $100^{\circ} \mathrm{F}$. The patient died at $9 \mathrm{P} . \mathrm{M}_{\text {. }}$ on the $2 \mathrm{Ist}$, and the temperature at death was $98^{\circ}$. A few days before death a bedsore formed over the sacrum.

Necropsy-CProf. Hamilton conducted the post-mortem examination, and, although every cavity and organ were examined with great care, only the state of the brain need be given here in detail. The lungs, heart, liver, spleen, and kidneys were studded with grey gelatinous tubercle nodules of the size of mustard seed; no enlarged bronchial glands were found, and no cheesy nodule in the thorax or abdomen. The brain weighed forty-four ounces; the pia mater generally over the cerebral hemispheres showed a little injection, more especially where the tubercles were situated; and the subarachnoid space contained a little more fluid than usual. On the surface of both hemispheres there were numbers of tubercle nodules in groups. On the left sile they were found on the ascending frontal at its middle, immediately opposite the origin of the second frontal convolution, grouped in a small area of about an inch in length. There was also a second group over the occipital lobe, and a few tubercles were seen also in the Sylvian fossa, but not nearly so numerous as on the right side. On the right side the tubercles were situated over the whole of the supra-maroinal gyrus, one or two over the ascending frontal close behind the upper limit of the third frontal convolution, and in the sylvian fussa they were present in large numbers along the bloodvessels, and all the membranes in this situation were studded over with them. Round about the tubercles there was little if any meningitis. The base of the brain was perfectly free fron any meningitis or tubercle. The superficial origin of the nerves appeared to be perfectly normal. On incising the pons Varolii, a caceons softened cavity of the size of a large pea was found situated abont its middle, mostly on the left sile, but also passing over the mirldle line and implicating part of the right. The locality of the tumour corresponded exactly with the origin of the fif th nerve on both sides. The cavity of the tumour contained a quantity of yellow purulent-looking fluid. On the under suiface of the cerebellum on the left side, immediately behind the floor of the fourth ventricle, there was a similar deposit, about the size of a small pea, beginning to liquefy.

Remar.s.-For some time after the patient was first seen it was impossible to form an accurate diagnosis; but in the light of the family history it seemed certain that tuberculosis would sooner or later develop. When the acute symptoms set in, tubercular meningitis at once suggested itself as the cause; but on my first using the oplithalmoscope, I was struck by the presence of optic neuritis in the left eye and its absence in the right. Severe headache, sickness, and optic neuritis in one eye made the presence of a distinct lesion of the brain certain. When ulceration of the left cornea appeared, I at once diagnosed a lesion of the 
pons situated near and affecting the nuclens of the fifth nerve. In THE LANCET of Dec. 11th, 1886, I published a case of tumour of the pons Varolii, where ulceration of the cornea appeared shortly before death, and where its late appearance was due to the fact that the tun.our began on the surface of the pons, and for a time the only nerves affected were the sixth and seventl. As the tuniour extended into the pons the fifth nerve became involved, and there followed neuro-paralytic ophthalmia with ulceration and perforation of the cornea. The case which forms the sulject of this communication is interesting, if not unique: in the first place, because of the nature, the site, and the results of the lesion, a small cheesy nodule in the pons giving rise to acute general tuberculosis; and, secondly and chiefly, because ulceration, more correctly necrosis, of the cornea was the only special symptom present by which it was possible to localise the lesion. The facial paresis followed the corneal affection, was not at all well marked, and might easily have been overlooked.

Aberdeen.

TWO CASES OF

\section{FRACTURE OF THE SPINE TREATED BY TREPHINING.}

By HERBERT W. ALLINGHAM, F.R.C.S., SURGEON TO THE GREA'T NORTHERN CENTRAL HOSPITAI, ETC.

THE following two cases came under my care at the Great Northern Central Hospital last year. Although the results have not been very satisfactory, yet $I$ deem it right to put them on record, as I think one or two important points may be learnt in considering the question of spinal surgery.

John $\mathbf{E}-$ aged thirty-one, was admitted into the hospital on July 23rd, 1888, having fallen between thirty and forty feet from the top of a house. He is said to have fallen on to his head, his body doubling backwards. On admission he had complete paralysis of the lower limbs, but no priapism. He also complained of a pain around his waist as if he were being constricted by an iron band; this pain was on a level with the ensiform cartilage. No deformity could be felt or seen about the back. He was perfectly conscious. Temperature $95.8^{\circ}$. A few hours later he complained of "pins and needles" in the hands, and he had to have a catheter passed. He remained in about the same state until about Aug. 10th, when his urine began to dribble away unconsciously, the bladder sometimes being completely empty on the passage of a catheter and sometimes containing an ounce of urine, evidently showing that the bladder centre was becoming involved; at the same time, his temperature began to rise, reaching $103^{\circ}$ and $104^{\circ}$; and, moreover, the line of loss of sensation was getting higher. From these symptoms $I$ inferred that ascending and descending changes were beginning to take place in the cord. Accordingly, on Aug. 16th, about three months after the accident, I trephined his spine, hoping I might relieve the pressure on the cord and also stop the inflammatory changes that were evidently spreading from the seat of the accident. The patient being placed on his stomach chloroform having been given), an incision about twelve inches in length was made down the centre of the back, over the spinous processes of the fifth, sixth, and seventh dorsal vertebræ. The muscles on each side of the spinous processes were then held back by retractors, and the spinous processes and laminæ being exposed, it was seen that the laminæ of the sixth vertebra were very badly fractured and depressed, being pushed under the laminie of the vertebra above. With great trouble these were removed, the spinous process and laminæ of the vertebræ above and below being snipped through with bone forceps and removed. The cord, being completely exposed for about four inches, looked rather bruised, but pulsated freely on the pressure being removed; at the same time it seemed to be curved somewhat backwards, this being probably caused by some displacement of the body of the sixth vertebra. The theca was not opened. The wound was then thoroughly washed with carbolic lotion ( 1 in 40), and a large drainagetube placed in the wound, extending from its upper to its lower angle. No deep sutures were used, the skin being sutured with silver sutures and antiseptic dressings applied, the operation taking an hour and a half. The same nights the patient slept well. The catheter was passed, but only two ounces of urine were drawn off, as most of it had dribbled away.

The next day (Aug. 17th) the patient was very comfort. able, the temperature being lower. He said he had a funny sensation in the abdomen, as if mice were running over it: also a feeling of coldness. His bladder contained more urine.

Aug. 18th.- The back was dressed, and looked very quiet. and well

22nd.-Temperature $101^{\circ}$. The wound was dressed, and had absolutely healed by first intention. Much less dribbling: of urine, and last evening the bladder was fairly full of clear" urine. No return of sensation. Knee-jerk absent; superficial sole reflex seemed rather more marked.

Sept. 3rd.-Dr. Beevor kindly examined the patient, and found that the anæsthesia in the middle line began exactly five inches above the umbilicus, half an inch lower in the two mammary lines. Pin prick felt as a twitch two inches and three-quarters from the umbilicus, but not felt as a prick till three inches and three-quarters above the umbilicus. No epigastric or abdominal reflexes.

7 th. - Patient had a rigor, temperature going up to $104^{\circ}$; and another occurred the same night.

1lth.-Much better; no more rigors. Sits up daily for a few hours. Said he felt the passage of the catheter, and complained of a good deal of spasm in the abdomen, and of shooting and jumping in the legs.

On Nov. 9uh, Dr. Beevor kindly examined the patient again, with the following results:--Right side: (1) Middle line in front, in line of anæsthesia, an inch and a half above umbilicus ; (2) nipple line, the same level; (3) mid.. axillary line, lower margin of the true ribs; (4) Scapular basal line, sane horizontal level as $(3)$; (5) middle line: behind first lumbar vertebra. Left side: (1) Middle line in front, same as on right side; (2) nipple line, same as on right side; (3) mid-axillary line, tenth rib; (4) scapular basal line, twelfth rib; (5) middle line behind, same as on right side. Analgesia: In middle line, one inch above anæsthetic line; left side, half an inch ditto; right side, half an inch ditto; in middle line behind, one inch ditto. Legs: Knee-jerk absent; no ankle-clonus ; plantar reflex rather active. No sensation or muscular sense in legs. Epigastric reflexes present; abdominal reflex absent. So that it will be seen by the above that he had improved as far as return of sensation about four inches.

On Jan. 26 th the line of anæsthesia had not altered. The legs were contracted and stiff. Some bedsores that had formed were all healed. Knee-jerk absent; no ankle-clonus. The patient after this left the hospital. On April 5th I heard from the patient. He was then no worse, but did not think there was any marked improvement.

The next case is that of Annie C-, aged twenty-one, who was brought to the hospital on Aug. 3lst, 1888, having jumped from the top storey of a house, a height of about forty feet. She broke her fall by catching against some iron railings. On admission she complained of pain in her back, was cold and collapsed, but moved her arms freely. There were complete paralysis, anæsthesia, and analgesia over the lower part of the trunk and lower extremities, the latter commencing at a point in the middle line seven inches above the umbilicus, and in the mammary line six inches above the line of the umbilicus. The respiration was chiefly abdominal. She complained of great pain between the shoulder-blades, and on examining the back a distinct prominence could be seen corresponding to the fourth and fifth dorsal vertebrx. She complained also of a feeling of tightness and weight round the chest to a corresponding part. The epigastric and abdominal reflexes were gone. She had complete retention of urine. Knee-jerks present, but diminished; no ankle-clonus; plantar reflexes increased. There were no signs of injury to any other part of the body.

On September 5th, five days after the accident, as she remained in the same condition (no improvement), chloroform was given, and an incision about ten inches in length was made over the spinous processes of the third, fourth, fifth, and sixth dorsal vertebræ. The muscles being separated from the spinous processes, it was found that the lamine of the fourth dorsal vertebra were badly fractured. I therefore removed the spinous process and laminæ of the third, fourth, and fifth vertebræ, and exposed the cord for about four inches. It was then seen that the cord was much bruised 